\title{
MENINGKATKAN KEMAMPUAN BERHITUNG PERMULAAN ANAK USIA DINI MELALUI MEDIA PERMAINAN STICK ANGKA
}

\author{
Gytta Ayu Nur Wulan ${ }^{1}$ \\ Dudung Priatna ${ }^{2}$ \\ Moh. Helmi Ismail ${ }^{3}$
}

\begin{abstract}
ABSTRAK
Penelitian ini merupakan studi tentang peningkatan berhitung permulaan anak usia dini melalui media permainan stick angka. Latar belakang penelitian ini bertolak dari kurang optimalnya kemampuan berhitung permulaan anak usia dini di TK Suka Haji. Dengan rumusan masalah, Bagaimana pelaksanaan pembelajaran dalam peningkatan kemampuan berhitung permulaan anak usia dini melalui media permainan stick angka dikembangkan pada kelompok B3 di TK Suka Haji dan Apakah kemampuan berhitung permulaan anak kelompok B3 TK Suka Haji meningkat setelah menggunakan media permainan stick angka. Tujuan dari penelitian ini yakni Untuk mengetahui bagaimana pelaksanaan pembelajaran dalam meningkatan kemampuan berhitung permulaan anak usia dini melalui media permainan stick angka dikembangkan di TK Suka Haji dan Untuk mengetahui apakah kemampuan berhitung permulaan anak kelompok B TK Sukahaji meningkat setelah menggunakan media permaian stick angka. Subjek penelitian ini yakni anak kelompok B3 TK Suka Haji Kecamatan Cileunyi Kabupaten Bandung, sebanyak 12 orang. Metode penelitian yang digunakan yakni penelitian tindakan kelas dengan model Elliot. Penelitian ini dilaksanakan 3 siklus dengan 3 tindakan pada setiap siklusnya. Instrumen penelitian yang digunakan yakni lembar observasi guru dan anak, catatan lapangan, dokumentasi dan lembar penilaian performa anak. Data yang didapatkan dianalisis melalui tiga teknik analisis data, yakni teknik analisis data kualitatif, kuantitatif dan triangulasi. Dalam kemampuan berhitung permulaan yang dikembangkan dalam penelitian ini yakni (a) Menyebutkan lambang bilangan 1 - 20; (b) Menggunakan lambang bilangan untuk menghitung; (c) Mencocokkan bilangan dengan lambang bilangan. Hasil penelitian berupa aktivitas dari siklus satu hingga siklus tiga memperlihatkan aktivitas anak dalam berhitung permulaan melalui media permainan stick angka, anak semakin mampu dalam hal berhitung permulaan. Selanjutnya untuk hasil dari analisis data dalam bentuk kualitatif dirubah menjadi data kuantitatif menunjukkan hasil yang meningkat. Data kuantitatif terkait penilaian dengan menggunakan skor BB, MB, BSH, dan BSB. Peningkatan yang diamati dilihat dari skor yakni BSB. Capaian penilaian bintang empat yang didapat dari siklus pertama sebesar $58,33 \%$, siklus kedua sebesar $75 \%$, siklus tiga sebesar $90,90 \%$. Dengan demikian dapat disimpulkan media permainan stick angka dapat menjadi salah satu alternatif untuk meningkatkan kemampuan berhitung permulaan anak usia dini. Bagi guru media permainan stick angka ini dapat menjadi salah satu alternatif dalam meningkatkan kemampuan berhitung permulaan untuk anak usia dini.
\end{abstract}

Kata Kunci : Kemampuan Berhitung Permulaan, Media Permainan Stick Angka

\footnotetext{
${ }^{1}$ gyttanurwulanl3@yahoo.com

${ }^{2}$ Dosen UPI Cibiru

${ }^{3}$ Dosen UPI Cibiru
} 


\section{A. PENDAHULUAN}

Berhitung merupakan suatu kegiatan melakukan, mengerjakan hitungan seperti menjumlah, mengurangi dan memanipulasi bilangan-bilangan dan lambang-lambang matematika (Putri, 2014, hlm. 3). Berhitung permulaan merupakan salah satu kemampuan yang sangat penting bagi anak yang perlu dikembangkan dalam rangka membekali anak dikehidupannya di masa depan. Berhitung merupakan dasar dari beberapa ilmu yang dipakai dalam setiap kehidupan manusia. Mengingat begitu pentingnya kemampuan berhitung bagi manusia, maka kemampuan berhitung ini perlu diajarkan sejak dini, dengan berbagai media dan metode yang tepat sehingga tidak dapat merusak pola perkembangan anak. Pembelajaran matematika pada anak sudia dini haruslah melalui cara yang sederhana dan tepat serta dilakukan secara konsisten dan kontinu dalam suasana yang kondusif dan menyenangkan, maka otak anak akan terlatih untuk terus berkembang sehingga anak dapat menguasai, dan bahkan menyenangi matematika tersebut. (Susanto, 2011, hlm. 65).

Beberapa teori yang mendasari perlunya permainan berhitung permulaan di Taman Kanak-Kanak permulaan menurut Departemen Pendidikan Nasional dalam Pedoman Pembelajaran Permainan Berhitung Permulaan (2007, hlm. 4) adalah sebagai berikut:

1) Tingkat perkembangan mental anak Menurut Jean Piaget bahwa kegiatan belajar memerlukan kesiapan dalam diri anak didik. Belajar sebagai suatu proses yang memerlukan aktifitas baik fisik dan psikis. Selain itu kegiatan pembelajaran pada anak harus disesuaikan dengan tahapan- tahapan perkembangan anak. Dimana anak usia TK berada pada tahapan pra-operasional kongkrit.

2) Masa peka berhitung permulaan pada anak Masa usia dini merupakan masa yang sangat strategis untuk mengenalkan berhitung permulaan, karena pada masa ini anak sangat peka terhadap rangsangan yang diterima dari lingkungan.

Sejalan dengan teori-teori yang telah dikemukakan, permainan berhitung permulaan di Taman Kanak-kanak dilakukan melalui tiga tahapan penguasaan berhitung di jalur matematika menurut Departemen Pendidikan Nasional dalam Pedoman Pembelajaran Permainan Berhitung Permulaan (2007, hlm. 6). yaitu:

1) Penguasaan Konsep

Pada tahap penguasaan konsep, pemahaman dan pengertian tentang suatu hal haruslah menggunakan benda dan peristiwa kongkrit, misalnya pengenalan warna, bentuk, dan menghitung bilangan.

2) Masa transisi

Pada tahap ini proses berfikir yang merupakan masa peralihan dari pemahaman kongkrit menuju pengenalan lambang yang abstrak, dimana benda kongkrit masih digunakan dan mulai dikenalkan bentuk dan lambangnya.

3) Lambang

Pada tahap ini lambang atau visualisasi dari berbagai konsep. Seperti lambang 7 untuk menggambarkan konsep bilangan tujuh, merah untuk menggambarkan konsep warna, besar untuk menggambarkan konsep ruang, dan persegi empat untuk menggambarkan konsep bentuk.

Adapun prinsip-prinsip berhitung permulaan menurut Departemen Pendidikan Nasional dalam Pedoman Pembelajaran Permainan Berhitung Permulaan (2007, hlm. 2) adalah sebagai berikut:

1) Permainan berhitung permulaan haruslah diberikan secara bertahap, diawali dengan menghitung benda- benda atau pengalaman peristiwa kongkrit yang dialami melalui pengamatan terhadap lingkungan sekitar.

2) Keterampilan serta pengetahuan tentang permainan berhitung permulaan diberikan secara bertahap menurut tingkat kesukarannya, misalnya dari kongkrit ke abstrak, mudah ke sukar, dan dari sederhana ke yang lebih kompleks.

3) Keberhasilan permainan berhitung yaitu jika anak-anak diberikan kesempatan berpartisipasi 
aktif dan dimotivasi untuk menyelesaikan masalah-masalahnya sendiri.

4) Permainan berhitung membutuhkan suasana atau kondisi yang menyenangkan dan rasa aman serta kebebasan bagi anak. Oleh karena itu diperlukan alat peraga atau media yang bersifat konkrit sesuai dengan benda yang sebenarnya (tiruan), menarik dan bervariasi, mudah digunakan dan tidak membahayakan.

5) Penggunaan bahasa dalam pengenalan konsep berhitung seyogyanya menggunakan bahasa yang sederhana dan jika memungkinkan mengambil contoh yang terdapat di lingkungan sekitar anak.

6) Dalam permainan berhitung anak dapat dikelompokkan sesuai dengan tahapan penguasaan yaitu tahap konsep, masa transisi, dan lambang.

7) Dalam mengevaluasi hasil perkembangan anak harus dimulai dari awal sampai akhir kegiatan.

Dari prinsip-prinsip tersebut dapat dikemukakan bahwa pelajaran berhitung bukanlah sesuatu hal yang menakutkan, tetapi merupakan pelajaran yang menyenangkan sehingga anak akan merasa membutuhkan karena cara mengajarkannya pun tepat sesuai dengan tahapan perkembangan usia anak usia dini.

Kata media berasal dari bahasa latin yaitu medius yang berarti perantara atau pengantar. Menurut bahasa Arab kata media berarti perantara atau pengantar pesan dari pengirim kepada penerima pesan. (Arsyad, 2011, hlm. 3).

Menurut Hamidjojo dalam Latuheru (Sundayana, 2015, hlm. 5) media adalah semua bentuk perantara yang digunakan oleh individu dalam menyampaikan atau menyebarkan informasi, ide, atau gagasan agar dapat tersampaikan kepada penerima.

Media pembelajaran merupakan suatu komponen sumber belajar yang mengandung bahan ajar instruksional yang bertujuan untuk memotivasi siswa dalam belajar. Adapun fungsi dan tujuan pengaplikasian media pembelajaran dalam mengembangkan kemampuan kognitif anak yaitu untuk memotivasi anak melakukan kegiatan pembelajaran, sebagai alat peraga untuk membantu memperjelas materi, untuk

mengembangkan kreatifitas anak, untuk membantu mencapai tujuan pembelajaran yang maksimal, serta sebagai wahana permainan bagi anak usia dini.

Permainan stick angka adalah suatu bentuk media pembelajaran berbasis permainan untuk menyampaikan suatu materi pembelajaran pada anak usia dini. Penggunaan permainan stick angka diharapkan lebih mudah untuk membantu anak memahami konsep berhitung agar lebih termotivasi dalam belajar berhitung permulaan. Media permainan stick angka yang akan digunakan dalam penelitian adalah permainan yang terbuat dari tongkat, batang, atau potongan kayu. Sedangkan angka merupakan suatu symbol untuk hitungan dengan symbol pokok yaitu 0,1,2,3,4,5,6,7,8, dan 9. (Ma'rifah, 2014, hlm. 20).

Sejalan dengan teori di atas menurut Putri (2014, hlm. 3) media stick angka yaitu salah satu upaya untuk mengembangkan kemampuan pemahaman angka pada anak. Media stick angka dapat dilakukan melalui kegiatan permainan, menyebutkan urutan bilangan dan mengenal lambang bilangan, menghubungkan angka dengan tulisannya. Salah satu upaya yang harus di lakukan guru adalah dengan menggunakan media (alat peraga) yang lebih kreatif dan inovatif. Pemanfaatan media yang lebih kreatif diharapkan dapat menarik perhatian anak didik, sehingga anak lebih termotivasi dan bersemangat dalam melaksanakan pembelajaran. Disamping itu kegiatan belajar mengajar juga dapat dikembangkan. Kegiatan belajar mengajar tidak hanya berpusat pada guru saja, anak didik juga perlu dilibatkan dan diaktifkan.

\section{B. METODE PENELITIAN}

Desain penelitian yang akan digunakan dalam penelitian ini adalah desain penelitian tindakan kelas. Penelitian tindakan kelas berfokus pada kegiatan pembelajaran berupa tingkah laku atau perilaku guru dan peserta didik dalam berinteraksi. Penelitian tindakan kelas bertujuan 
untuk memperbaiki suatu pembelajaran yang dilakukan secara terus menerus dan bertahap sampai didapat hasil yang terbaik.

Sebagaimana yang dikemukakan oleh Abidin $(2011, \mathrm{hlm} .217)$ penelitian tindakan kelas adalah penelitian yang dilakukan untuk memecahkan suatu masalah, mengkaji suatu langkah pemecahan itu sendiri atau memperbaiki suatu proses pembelajaran secara langsung maupun bersiklus. Penelitian tindakan kelas yaitu suatu penelitian yang dilakukan oleh guru di dalam kelasnya melalui refleksi diri, yang bertujuan untuk memperbaiki kinerjanya sebagai guru, sehingga hasil belajar peserta didiknya menjadi meningkat (Wardhani, dkk. 2000, hlm. 4).

Subjek penelitian yang diteliti adalah anak kelompok B3 di TK Suka Haji yang beralamat di Jl. Pasantren No.1A RT.02 RW.17 Desa Cimekar Kecamatan Cileunyi Kabupaten Bandung. Subjek penelitian merupakan anak usia dini yang berusia 5-6 tahun dan terdiri dari 12 siswa. 5 siswa laki-laki dan 7 siswa perempuan.

Instrument penelitian yang akan digunakan sebagai alat penunjang pengumpulan data dalam penelitian ini, yakni: lembar penilaian performa, lembar observasi, dokumentasi, dan catatan lapangan.

Lembar penilaian performa anak dikembangkan dengan tiga indikator yaitu; menyebutkan lambang bilangan (120), menggunakan lambang bilangan untuk berhitung, dan mencocokkan bilangan dengan lambangnya.

Data yang berhasil dikumpulkan melalui berbagai teknik dan instrument yang digunakan, akan menghasilkan dua data yaitu data kualitatif dan kuantitatif. Data kualitatif ini dianalisis secara deskriptif dengan menggunakan teknik presentase untuk melihat kecenderungan yang terjadi dalam kegiatan. Teknik analisis data kualitatif dilakukan dengan cara menggabungkan beberapa data yang didapat dari hasil observasi, dan dokumentasi. Menurut Sugiyono (2013, hlm. 15) data kualitatif menggunakan instrument berupa orang atau human instrument, dalam penelitian berarti peneliti itu sendiri. Analisis data kualitatif bersifat induktif berdasarkan fakta yang ditemukan di lapangan kemudian dikonstruksikan menjadi suatu hipotesis.

Data kuantitatif ini digunakan untuk mengetahui kemajuan peningkatan siswa setelah dilaksanakan tindakan; data kuantitatif ini didapat dari instrument respon performa, dimana dari data yang diperoleh diubah dari skor menjadi skala nilai, dan dihitung melalui rumus. Menurut Sugiyono (2013, hlm. 14) data kuantitatif didapat dari instrument penelitian, data yang sudah terkumpul selanjutnya akan dianalisis dengan menggunakan rumus statistic deskriptif sehingga dapat mengetahui apakah hipotesis yang dirumuskan pada penelitian terbukti atau tidak.

Untuk menyimpulkan data keseluruhan dalam keberhasilan peningkatan kemampuan anak dalam pembelajaran, maka cara pengumpulan datanya adalah sebagai berikut menurut Sudijono (2000, hlm. 40) Rumus yang digunakan yaitu:

$$
\mathrm{P}=\mathrm{F} \times \frac{100 \%}{\mathrm{~N}}
$$

Keterangan:

$\mathrm{P}$ : Angka presentase (\%) F : Frekuensi yang dicari N : Jumlah responden 100 :

Bilangan konstanta

Adapun pelaksanaan pembelajaran dalam meningkatkan kemampuan berhitung permulaan anak usia dini melalui media permainan stick angka dilakukan berhasil jika pembelajaran minimal mencapai rata-rata persentase keberhasilan yang diharapkan adalah > 75\% atau berkembang sesuai harapan (BSH) dari sejumlah anak yang ada di kelas.

Guna mencapai keabsahan data digunakan teknik yang dapat menjamin kebenaran hasil penelitian, teknik tersebut merupakan triangulasi. Triangulasi merupakan gabungan dari berbagai teknik pengumpulan data yang telah ada. Dalam penelitian kualitatif pada bidang PAUD, sebaiknya menggunakkan penelitian dengan berbagai teknik sehingga hasilnya menjadi data yang dapat dipercaya dan pasti. Dalam pengujiannya dilakukan dengan menggunakan 
teknik pengumpulan data yang berbeda-beda untuk mendapatkan data dari sumber yang sama.

\section{PEMBAHASAN}

Pada bagian temuan penelitian akan dijabarkan hasil penelitian. Penelitian yang dilakukan terdiri dari 3 siklus yang masing-masing siklusnya terdiri dari 3 tindakan. Setiap tindakan dilakukan melalui kegiatan yang menggunakan media permainan stick angka. setiap kegiatan tersebut akan diamati peningkatan anak dalam kemampuan berhitung permulaan.

\section{Siklus I}

Hasil yang ditemukan setelah dilakukannya siklus I pada indikator 1 yaitu sebesar $38,23 \%$, indikator 2 sebesar $20,20 \%$, dan indikator 3 sebesar $25,75 \%$. Berdasarkan analisis di atas terdapat temuan yang menjadi kendala pada saat melaksanakan penelitian berlangsung sehingga perlu adanya perbaikan pada siklus selanjutnya. Adapun hal-hal yang harus diperbaiki adalah akan dibuat reward berupa sticker-sticker yang menarik bagi anak. Media permainan stick angka akan dibuat lebih menarik dan diberi gambar sesuai materi. Dan guru harus lebih detail lagi dalam menjelaskan langkah-langkah menggunakan stick angka.

Penulis dapat menyimpulkan bahwa dalam siklus I tindakan 1 kemampuan berhitung permulaan anak masih belum terlihat. Pada tindakan 2 kemampuan berhitung permulaan anak mulai terlihat peningkatan dan antusiasnya dalam mengikuti kegiatan pembelajaran. Begitupun pada tindakan 3 anak sudah terlihat antusias dalam mengikuti kegiatan serta sudah mulai terlihat peningkatannya. Di bawah ini kemampuan berhitung permulaan anak melalui media permainan stick angka dilihat dari skor BSB (Berkembang Sangat Baik) pada siklus I sebagai berikut.

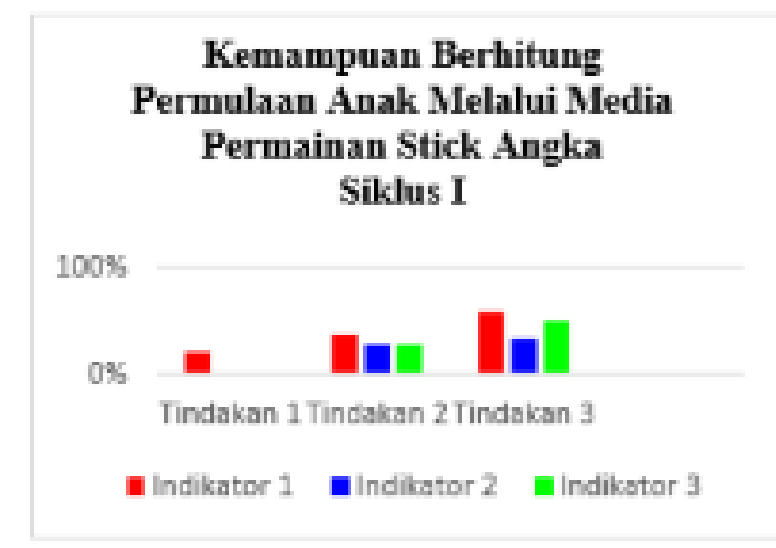

Gambar 1

Kemampuan Berhitung Permulaan Anak Melalui Media Permainan Stick Angka Siklus I

Pada siklus I ini ternyata hasil yang dicapai anak masih belum ada peningkatan karena baru $58,33 \%$ belum memenuhi target yang diharapkan yaitu $>75 \%$. Untuk itu peneliti merencanakan untuk melakukan kegiatan siklus II.

\section{Siklus II}

Hasil yang ditemukan setelah dilakukannya siklus II pada indikator 1 yaitu sebesar $48.61 \%$, indikator 2 sebesar $38,33 \%$, dan indikator 3 sebesar $56,11 \%$. Berdasarkan analisis di atas terdapat temuan yang menjadi kendala pada saat melaksanakan penelitian berlangsung sehingga perlu adanya perbaikan pada siklus selanjutnya. Adapun hal-hal yang harus diperbaiki adalah stick angka akan diberi warna yang lebih beragam. Dan akan dibuat media pendukung 
yang lebih besar agar memudahkan anak dalam pembelajaran.

Penulis dapat menyimpulkan bahwa dalam siklus II tindakan 1 kemampuan berhitung permulaan anak sudah terlihat. Pada tindakan 2 kemampuan berhitung permulaan anak sudah terlihat peningkatan dan antusiasnya dalam mengikuti kegiatan pembelajaran. Begitupun pada tindakan 3 anak sudah terlihat antusias dalam mengikuti kegiatan serta sudah mulai terlihat peningkatannya. Di bawah ini kemampuan berhitung permulaan anak melalui media permainan stick angka dilihat dari skor BSB (Berkembang Sangat Baik) pada siklus II sebagai berikut.

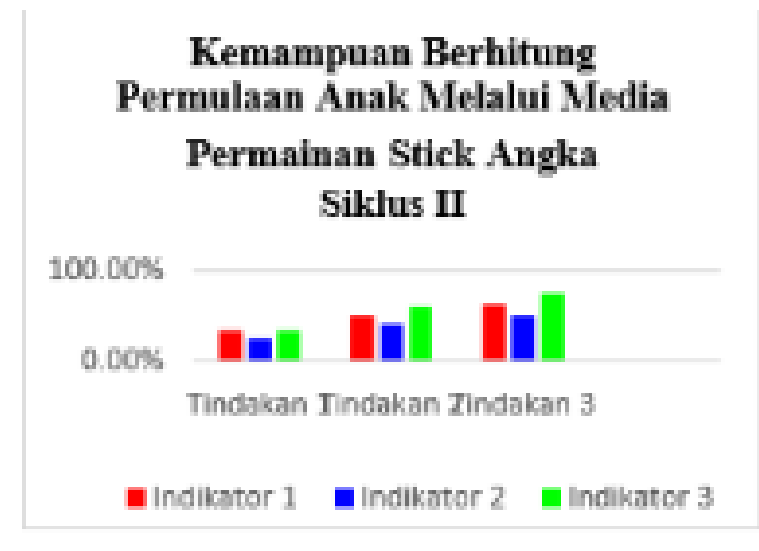

Gambar 2

Kemampuan Berhitung Permulaan Anak Melalui Media Permainan Stick Angka Siklus II

Pada siklus II terjadi peningkatan sesuai harapan yaitu $75 \%$ karena sudah mencapai target yang ditetapkan dalam indikator pencapaian yaitu minimal $75 \%$.

\section{Siklus III}

Hasil yang ditemukan setelah dilakukannya siklus III pada indikator 1 yaitu sebesar $73,73 \%$, indikator 2 sebesar $54,20 \%$, dan indikator 3 sebesar $70,70 \%$. Berdasarkan analisis di atas setelah dilaksanakan penelitian dari siklus I, II, dan III dapat disimpulkan bahwa pembelajaran melalui media permainan stick angka berhasil meningkatkan kemampuan berhitung permulaan anak di kelompok B3 TK Suka Haji. Hal ini dapat dilihat dari peningkatan disetiap indikator dari siklus I, II, dan III. proses pelaksanaan tindakan pada siklus III sudah meningkat dengan baik. Kelemahan yang ada pada siklus sebelumnya dapat teratasi dengan baik. Peningkatan terlihat dari tercapainya indikator yang telah ditetapkan.

Penulis dapat menyimpulkan bahwa dalam siklus III tindakan 1 kemampuan berhitung permulaan anak sudah terlihat. Pada tindakan 2 kemampuan berhitung permulaan anak sudah terlihat peningkatan dan antusiasnya dalam mengikuti kegiatan pembelajaran. Begitupun pada tindakan 3 anak sudah terlihat antusias dalam mengikuti kegiatan serta sudah mulai terlihat peningkatannya. Di bawah ini kemampuan berhitung permulaan anak melalui media permainan stick angka dilihat dari skor BSB (Berkembang Sangat Baik) pada siklus III sebagai berikut. 


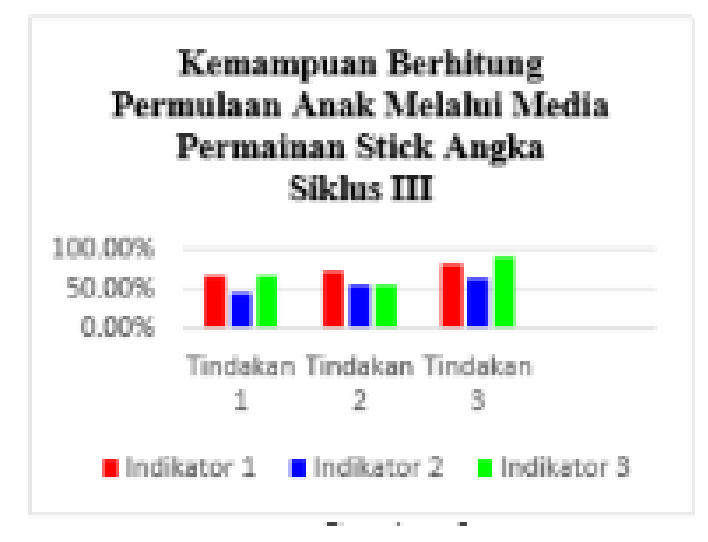

Gambar 3

Kemampuan Berhitung Permulaan Anak Melalui Media Permainan Stick Angka Siklus III

Berdasarkan analisis di atas setelah dilaksanakan penelitian dari siklus I, II, dan III dapat disimpulkan bahwa pembelajaran melalui media permainan stick angka berhasil meningkatkan kemampuan berhitung permulaan anak di kelompok B3 TK Suka Haji. Hal ini dapat dilihat dari peningkatan disetiap indikator dari siklus I, II, dan III. proses pelaksanaan tindakan pada siklus III sudah meningkat dengan baik. Kelemahan yang ada pada siklus sebelumnya dapat teratasi dengan baik. Peningkatan terlihat dari tercapainya indikator yang telah ditetapkan. Pada kegiatan yang dilaksanakan di siklus III hasilnya mencapai 90,90\%.

Dapat dilihat pada grafik dibawah ini terdapat presentase hasil peningkatan kemampuan berhitung permulaan anak dalam menyebutkan lambang bilangan (1-20) mulai dari siklus I, II, dan III.

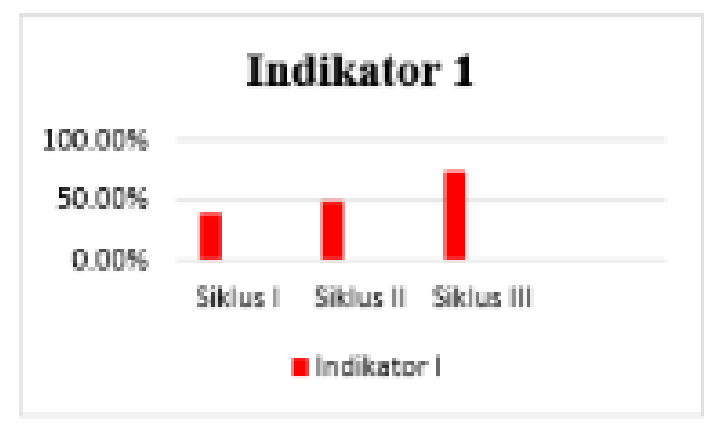

Gambar 4

\section{Hasil Peningkatan Kemampuan}

Berhitung Permulaan Anak dalam Menyebutkan Lambang Bilangan (1 - 20)

Berdasarkan data pada grafik di atas dapat terlihat peningkatan kemampuan kemampuan berhitung permulaan dalam menyebutkan lambang bilangan (1-20) melalui media permainan stick angka. 


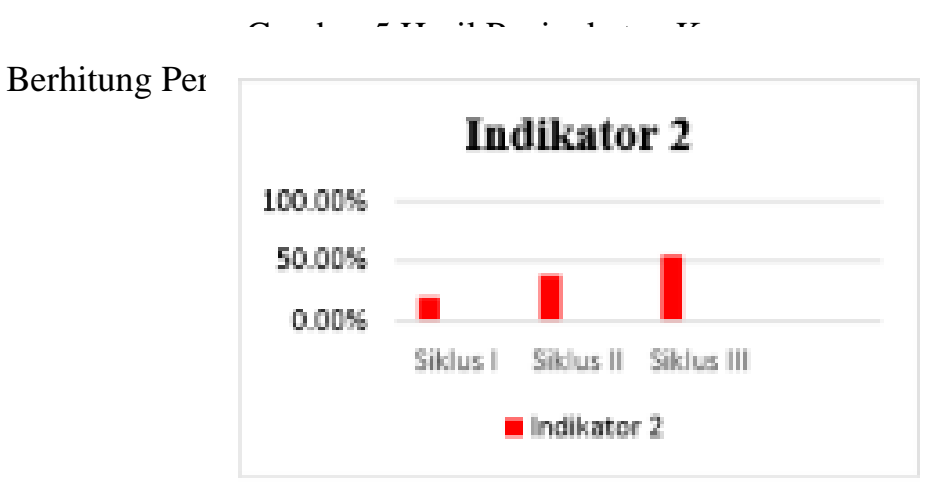

Igan untuk

Berdasarkan data pada gambar grafik di atas dapat terlihat peningkatan kemampuan berhitung permulaan anak dalam menggunakan lambang bilangan untuk menghitung (1-10) melalui media permainan stick angka.

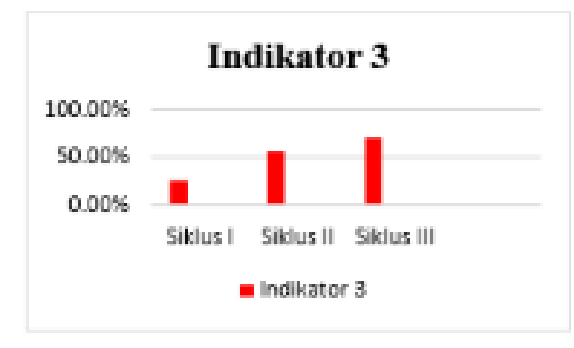

Gambar 6 Hasil Peningkatan Kemampuan

Berhitung Permulaan Anak dalam Mencocokkan Bilangan dengan Lambang Bilangan (1-20)

Berdasarkan data pada gambar grafik di atas dapat terlihat peningkatan kemampuan berhitung permulaan anak dalam mencocokkan bilangan dengan lambang bilangan (1-20).

\section{PENUTUP}

Berdasarkan pada hasil penellitian yang telah dilakukan, maka dapat diambil beberapa simpulan sebagai berikut :

1. Kemampuan berhitung permulaan anak usia dini kelompok B3 di TK Suka Haji sebelum menggunakan media permainan stick angka masih belum optimal. Hal tersebut terlihat dari pengamatan awal peneliti selama melaksanakan kegiatan praktek lapangan. Dengan begitu perlu diperbaiki melalui pemberian bantuan berupa media permainan stick angka kepada anak kelompok B3.

2. Kemampuan berhitung permulaan anak usia dini kelompok B3 di TK Suka Haji setelah menggunakan media permainan stick angka terdapat peningkatan. Hal ini dapat dilihat dari antusias, respon, kemampuan berpikir, sikap ataupun tindakan anak yang dilakukan selama mengikuti suatu permainan. Siklus I anak terlihat antusias dan merespon kegiatan berhitung permulaan melalui media permainan stick angka, namun masih ada beberapa siswa yang belum mengerti dan kebingungan dalam memainkan setiap permainan dengan media stick angka. Siklus II anak terlihat antusias, merespon dan bersemangat namun ada beberapa anak yang mengobrol dan sibuk sendiri memainkan media yang peneliti berikan. Pada siklus terakhir yakni siklus III anak-anak terlihat begitu sudah menguasai media permainan berhitung, dari mulai menyebutkan lambang bilangan (120), menggunakan lambang 
bilangan untuk menghitung, dan mencocokkan bilangan dengan lambang bilangannya. Sehingga pada siklus III ini anak sudah baik dan terlihat peningkatannya dalam berhitung permulaan melalui media permainan stick angka.

3. Adapun pelaksanaan pembelajaran dalam meningkatkan kemampuan berhitung permulaan anak usia dini melalui media permainan stick angka dilakukan berhasil jika pembelajaran minimal mencapai rata-rata persentase keberhasilan yang diharapkan adalah $>75 \%$ atau berkembang sesuai harapan (BSH) dari sejumlah anak yang ada di kelas. Meningkatnya kemampuan berhitung permulaan anak terjadi setiap siklusnya. Peningkatan terjadi disetiap siklus, dilihat dari perolehan skor BSB. Capaian penilaian bintang empat yang didapat dari siklus pertama sebesar 58,33\%, siklus kedua sebesar 75\%, siklus tiga sebesar 90,90\%.

\section{DAFTAR PUSTAKA}

Abidin, Yunus. (2011). Penelitian Pendidikan Dalam Gamitan Pendidikan Dasar Dan Paud. Bandung: Rizqi.

Arsyad, Azhar. (2011). Media Pembelajaran. Jakarta: Rajawali Pers.

Departemen Pendidikan Nasional. (2007). Pedoman Pembelajaran Permainan Berhitung Permulaan Di Taman Kanak-Kanak. Jakarta: Direktorat Pembinaan TK dan SD.

Ma'rifah, S.Pd. (2014). Upaya Meningkatkan Berhitung Permulaan Menggunakan Permainan Stick Angka Di Kelompok A Tk Dharma Wanita Persatuan Meduran Manyar Gresik. Pengembangan Profesional Keguruan. Gresik: Tidak Diterbitkan.

Putri, L. (2014). Upaya meningkatkan kemampuan berhitung permulaan menggunakan strategi bermain stick angka di Paud. Belia jurnal: Jurnal Ilmiah PG-PA UD IKIP Veteran Semarang, 2 (2), hlm. 3.

Sudijono, Anas. (2000). Pengantar Statistik Pendidikan. Jakarta: Rajawali Press.

Sugiyono. (2013). Metode Penelitian Pendidikan Pendekatan Kuantitatif, Kualitatif, dan R\&D. Bandung: Alfabeta.

Sundayana, H. Rostina. (2015). Media dan Alat Peragadalam Pembelajaran Matematika. Bandung: Alfabeta.

Susanto, Ahmad. (2011). Perkembangan anak usia dini. Jakarta: Kencana. Wardhani, IGAK dkk. (2000). Penelitian Tindakan Kelas. Jakarta: Universitas Terbuka. 